\title{
"Impact of the Basel IV framework on securitization and performance of commercial banks in South Africa"
}

\begin{tabular}{|c|c|}
\hline \multirow{3}{*}{ AUTHORS } & Damilola Oyetade iD https://orcid.org/0000-0003-0120-5385 \\
\hline & Adefemi A. Obalade (D https://orcid.org/0000-0001-6062-1632 \\
\hline & Paul-Francois Muzindutsi iD https://orcid.org/0000-0002-4819-8218 \\
\hline ARTICLE INFO & $\begin{array}{l}\text { Damilola Oyetade, Adefemi A. Obalade and Paul-Francois Muzindutsi (2020). } \\
\text { Impact of the Basel IV framework on securitization and performance of } \\
\text { commercial banks in South Africa. Banks and Bank Systems, 15(3), 95-105. } \\
\text { doi:10.21511/bbs.15(3).2020.09 }\end{array}$ \\
\hline DOI & http://dx.doi.org/10.21511/bbs.15(3).2020.09 \\
\hline RELEASED ON & Thursday, 27 August 2020 \\
\hline RECEIVED ON & Friday, 12 June 2020 \\
\hline ACCEPTED ON & Wednesday, 05 August 2020 \\
\hline & $((c)) \overline{E Y}$ \\
\hline LICENSE & $\begin{array}{l}\text { This work is licensed under a Creative Commons Attribution } 4.0 \text { International } \\
\text { License }\end{array}$ \\
\hline JOURNAL & "Banks and Bank Systems" \\
\hline ISSN PRINT & $1816-7403$ \\
\hline ISSN ONLINE & $1991-7074$ \\
\hline PUBLISHER & LLC "Consulting Publishing Company "Business Perspectives" \\
\hline FOUNDER & LLC "Consulting Publishing Company "Business Perspectives" \\
\hline \multirow[b]{2}{*}{ NUMBER OF REFERENCES } & $\begin{array}{ll}=-5 \\
= \pm=-\end{array}$ \\
\hline & NUMBER OF FIGURES \\
\hline 46 & 5 \\
\hline
\end{tabular}

(C) The author(s) 2022. This publication is an open access article. 


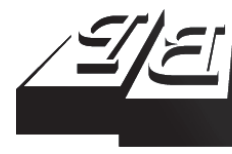

\section{BUSINESS PERSPECTIVES}

(2)

LLC "CPC "Business Perspectives" Hryhorii Skovoroda lane, 10, Sumy, 40022, Ukraine www.businessperspectives.org
Received on: $12^{\text {th }}$ of June, 2020 Accepted on: $5^{\text {th }}$ of August, 2020 Published on: $2^{\text {th }}$ of August, 2020

(C) Damilola Oyetade, Adefemi A. Obalade, Paul-Francois Muzindutsi, 2020

Damilola Oyetade, Ph.D. Candidate (Finance), School of Accounting, Economics and Finance, University of KwaZulu-Natal, South Africa.

Adefemi A. Obalade, Postdoctoral Research Fellow (Finance), School of Accounting, Economics and Finance, University of KwaZulu-Natal, South Africa.

Paul-Francois Muzindutsi, Associate Professor of Finance, School of Accounting, Economics and Finance, University of KwaZulu-Natal, South Africa. (Corresponding author)
This is an Open Access article, distributed under the terms of the Creative Commons Attribution 4.0 International license, which permits unrestricted re-use, distribution, and reproduction in any medium, provided the original work is properly cited.

Conflict of interest statement: Author(s) reported no conflict of interest
Damilola Oyetade (South Africa), Adefemi A. Obalade (South Africa),

Paul-Francois Muzindutsi (South Africa)

\section{IMPACT OF THE BASEL}

IV FRAMEWORK ON

SECURITIZATION AND

PERFORMANCE OF COMMERCIAL BANKS IN SOUTH AFRICA

\begin{abstract}
Securitization has been used as a tool for bank funding, liquidity, risk management, and performance for over two decades. However, securitization activities were negatively affected by the recent financial crises, which led to stricter regulations of banks' off-balance-sheet activities. This study examined the possible impacts of the Basel IV capital requirements on securitization activities and the performance of commercial banks in South Africa if implemented. The study used aggregated financial data of selected South African commercial banks to create a sample representative projection as if the selected banks had implemented the Basel IV capital requirements between 2002 and 2018. The simulated data were analyzed and compared to Basel III data using panel data analysis under certain assumptions, while other conditions held constant. The results revealed that the implementation of the Basel IV capital requirements will have a significant positive impact on securitization activities of commercial banks in South Africa. However, higher capital requirements of Basel IV may have no significant impact on performance of securitizing banks but it can protect banks from securitization exposure.
\end{abstract}

\section{Keywords}

securitization, Basel regulations, bank risk, riskweighted assets

\section{JEL Classification G18, G21, G28}

\section{INTRODUCTION}

Securitization involves the pooling of traditional class assets of banks (mortgage loans, commercial loans, credit card loans), bundling and selling in units by another entity known as special purpose vehicle (SPV) to investors in the securitization market with the aim of securing immediate liquidity (Jablecki, 2009). Consequently, banks can use the securitization process to take risks by holding unduly low capital reserves that are not commensurate with their risk exposures. This was observed among certain US banks during the 2000s and was among the factors that led to the 2008 global financial crisis (Balin, 2008).

South Africa is a leader with securitization from financial and non-financial originators in Africa (The Banking Association South Africa, 2019). The South African securitization market was not adversely affected by the 2008 financial crisis due to the strong national financial compliance and securitization regulations (Prinsloo, 2009), which prevented ill-conceived securitization practices in countries experiencing the negative effects of the financial crises. In addition, South African banks that engage in securitization are diversified and are highly capitalized (Moyo \& Firer, 2008; Nkopane, 2017). Despite this, 
securitization activities from commercial banks in South Africa declined in the same year of the global financial crises, while securitization activities by non-financial institutions in South Africa continued to grow (Bloomberg Online Database, 2019; White, 2011). White (2011) attributed the cause of decline to the implementation of the Basel II accord in 2008, which forced South African commercial banks to implement conservative risk management measures. As a result, the upgrade in risk management in accordance with one of the three pillars of Basel II led to fewer securitization activities from the South African banks compared to the banks in developed markets (Prinsloo, 2009; White, 2011).

The Basel Committee on Bank Supervision was established in 1974, and since its inception, has established a series of regulations on capital and liquidity requirements commonly known as Basel Accords. The first Basel accord is known as Basel I introduced in 1988, followed by Basel II in 2004, Basel III in 2009-2010 and the latest accord - Basel IV in 2016 with its implementation date set to be in the year 2022 with the aims of increasing bank resilience, promoting financial stability and restoring stakeholders' confidence (BCBS, 2017a; BCBS, 2016b; and Munoz \& Soler, 2017). The Basel IV accord introduces the standardization of risk-weighted assets for comparability and reliability of capital ratios (BCBS, 2016b; Munoz \& Soler, 2017). In addition to the Basel IV capital requirements, the Basel Committee also introduced a new securitization framework (STC) in 2016 in an attempt to re-establish securitization activities to support loans provisions from banks and to improve banks' access to funding through securitization as it was before the financial crises (BCBS, 2016a). STC is expected to eliminate the overly complex securitization process and limit the use of credit rating agencies in existence (BCBS, 2016a).

South Africa is a Basel member country, and, in principle, Basel member countries are obliged to comply with the changes in the Basel capital requirements (Beck, Jones, \& Knaack, 2019). South African banks were not affected by the recent financial crisis of 2008 due to their strong compliance with Basel regulation, however, securitization activities of commercial banks declined from 2008 as conservative risk measures of Basel II were adopted (The Banking Association South Africa, 2019; White, 2011). It is a matter for further research whether Basel IV will improve or deteriorate the securitization activities of the South African banks. This study, thus, investigates the impact of Basel IV on securitization activities and performance of securitizing banks of South African banks if adopted.

\section{LITERATURE REVIEW}

There exists a wide literature on the nexus between capital and bank performance. This section presents the reports of the existing theories and empirical studies on the relationship between Basel capital and securitization and bank performance.

\subsection{Theoretical literature}

Early theories suggested that securitization provided a means for transferring and reducing credit risk and allowed banks to specialize in activities in which they had no comparative advantage (Greenbaum \& Thakor, 1987; Pavel \& Phillis, 1987). A bank may be able to use securitization to improve its performance by lowering funding costs, improved credit risk management, and enhanced profitability (Casu, Clare, Sarkisyan, \& Thomas, 2013). Proponents of securitization, govern- ments, and banks maintained that securitization helped improve bank performance (Goddard, Liu, Molyneux, \& Wilson, 2013). Securitization is important for banks because it enables them to take more risk, improve their liquidity positions, and can also be used as a tool to achieve minimum capital requirements through regulatory capital arbitrage (Jablecki, 2009). One of the theories that explain securitization is the regulatory capital arbitrage. The theory suggests that banks engage in securitization by trading their loans that require at least 8 percent capital backing for government securities that requires 0 percent capital backing (Haubrich \& Wachtel, 1993; Jablecki, 2009). The regulatory capital arbitrage theory proposes that banks securitize quality loans with less risk and retain risky loans on their books (Bakoush, Abouarab, \& Wolfe, 2019; Dionne \& Harchaoui, 2008). Subsequently, Keys, Mukherjee, Seru, and Vig (2010) used an industry-rule of thumb that 
loans below a certain score of, for example, 620 are more difficult to securitize, thus suggesting that banks securitize quality loans. However, the 2008 financial crisis exposed the quality of loans that were being securitized as banks securitized their most problematic mortgage loans (Casu, Clare, Sarkisyan, \& Thomas, 2013).

\subsection{Impact of Basel capital requirements on securitization and bank performance}

The traditional function of bank capital is to protect depositors' funds against losses (Robinson, 1941). In this context, higher Basel capital requirements are meant to prevent bank failures and to ensure that risk exposures of banks are adequately protected by adequate amounts of capital (Dionne \& Harchaoui, 2008; Kargi, 2011). Saayman (2003) examined the impact of securitization on small bank liquidity in South Africa, and found that securitization had a positive impact on improving the liquidity position of banks provided it was done on a continuous basis. As for the link between securitization and Basel capital ratio, Uzun and Webb (2007) found that securitization was negatively related to bank capital ratio. Similarly, Dionne and Harchaoui (2008) show a negative relationship between capital ratios and level of securitization activities in Canada, while Cardone-Riportella, Samaniego-Medina, and Trujillo-Ponce (2010) posit that banks with less regulatory capital will have a greater incentive to securitize its loan assets.

Additionally, studies exist on the link between securitization and bank performance. Bank performance is the ability of a bank to generate sustainable profits. A bank's profit strengthens its capital position and enables a bank to re-invest its retained earnings to improve future profits (Carbó-Valverde, Marqués-Ibáñez，\& Fernandez, 2011). The empirical literature suggests that banks use funds from securitization to engage in more profitable and high-risk activities. In this context, banks receive immediate funds from the sale of illiquid loans and can grant more loans to generate increased income for banks (Kargi, 2011). In the 1970s, US banks utilized securitization when the channels for profit-making were shrinking and to finance the rising demand for home finance in the 1980s (Prinsloo, 2009; Saayman, 2003). Ghosh (2018) found that securitization significantly increased bank profits and leverage capital on 5,491 US banks that engage in securitization for the first time between 2001 and 2016. Similarly, Bakoush, Abouarab, and Wolfe (2019) found that securitization could have a positive impact on bank performance through four different transmission channels.

Conversely, Casu, Clare, Sarkisyan, and Thomas (2013) studied first-timer securitizing banks in the USA and showed that securitization did not improve bank performance, although securitizing banks were profitable ones. Additionally, Bannier and Hänsel (2008) found that there was no significant impact of securitization on bank performance in the sampled European banks. This was also supported by the finding of Cardone-Riportella, Samaniego-Medina, and Trujillo-Ponce (2010) who showed that securitization did not improve the performance of Spanish banks, the second-largest issuance of securitization in Europe after the UK. They showed that liquidity and the search for improved performance were the motives for Spanish banks to become involved in securitization. As a result, they concluded that Spanish banks used securitization to improve their efficiency ratios.

In addition to the above, the effect of securitization on bank profitability can be either positive or negative. The direct and positive effect on profitability is anticipated as securitization provides banks with more options to increase loan portfolios, liquidity to fund new investment opportunities for expansion and reduce credit risk, which may lead to more expected profits (Castellani, 2018; Jiangli \& Pritsker, 2008). The indirect and negative effects of securitization can lower the profitability of certain banks if there is more competition among the originators of securitized loans, which may depress banks' spreads in originating those types of loans and thereby reducing banks' profitability. Sarkisyan (2011) explained that the effect of securitization on bank performance may not show on the firsttime securitization but on a continuous basis. Krainer and Laderman (2014) showed that one 
of the reasons banks securitize is for the fee income on securitized assets, which can improve bank net interest income. It can be concluded from the literature that securitization may not affect bank performance if securitizing banks are not engaged in a variety of securitization activities. It may also require more than one-time securitization or continuous securitization to influence bank performance. This paper contributes specific empirical evidence to existing literature by evaluating the potential effect of Basel IV on securitization and bank performance.

\section{METHODOLOGY}

This article adopted a quantitative approach, which involved the analyses of the effect of Basel capitalization on securitization and, subsequently, the effect of securitization on bank performance. The study involved the analyses of secondary panel data, their interpretation, and drawing conclusions.

\subsection{Data and sample}

Panel data of annual observations of South African commercial banks dealing in securitization from 2002 to 2018 were used. A sample representative bank was constructed from the panel data consisting of individual commercial banks involved with originating securitization. Following Giordana and Schumacher (2017), this study assumed steps to simulate the banks' balance sheets as if they had complied with the Basel III and IV requirements from 2002. The selection of banks and the sample period are based on the availability of data. Annual financial data are sourced from the Bloomberg database, while securitization data were sourced from The Banking Association South Africa (2019). Macroeconomic data were sourced from the McGregor database and the Reserve Bank of South Africa. During the sample period, 30 securitizations were originated from five commercial banks (ABSA, FNB, Nedbank, Investec, and Standard Bank). The selected banks accounted for more than $90 \%$ of the South African banking industry's total assets (Sadien, 2017). Accounting ratios and bank-specific ratios selected for the study (see Table 1) are key performance measures widely used in literature (Ombaka \& Jagongo, 2018).

\subsection{Incorporation of the revised securitization framework into the study}

The South African commercial banks securitize diversified loans-mortgage and non-mortgage loans. The non-mortgage loans securitized are auto loans, credit card receivables, equipment leases, and trade receivables, amongst others, while mortgage loans securitized include residential home loans, commercial properties, and real estate (Bloomberg Online Database, 2019). The study incorporated securitization exposure into the Basel IV capital variables according to the Basel IV capital requirements. The securitization exposure was calculated using the simple transparent and comparable (STC) framework of 2016. A single securitization transaction issued by commercial banks has different tranches and ratings, to which risk weights are assigned based on the tranche ratings to measure the securitization exposure on each bank securitized assets (BCBS, 2016a). The securitization framework of 2016 provides standardized, internal and external approaches to calculate risk-weights to determine a given bank securitization exposure (BCBS, 2016a). However, SECERBA (external rating-based approach) can only be used due to the availability of information on ratings and tranches on all issued securitizations by the commercial banks in South Africa to measure securitization exposures. To avoid using interpolation for calculation of exposure on securitization with tranche maturity below five years and above one year as specified by the Securitization framework (BCBS, 2016a), all securitizations, originating from the sampled banks, with a minimum of five-year tranche maturity were considered. According to the STC framework, the most senior tranche within a securitization transaction is treated as a senior tranche in the calculation of RWA, even where there are several tranches that share a similar rating in the same transaction (BCBS, 2016a).

\subsection{Model specification}

The study examined the impact of Basel IV capital requirements on securitization and bank performance. This study adopted the methodologies of similar studies (Bakoush, Abouarab, \& Wolfe, 2019; and Dionne \& Harchaoui, 2008). Based on the simulated data, the sample bank was analyzed and compared with actual data (Basel III and II) to examine 
the impact of changes in Basel levels on the dependent variables $\left(\sec _{i t}\right.$ and $\left.\pi_{i t}\right)$. The first model tested the potential impact of Basel IV on securitization activities of commercial banks in South Africa.

$$
\begin{aligned}
& \mathrm{sec}=f[\text { Lev, Cap, Bankspe, macroec }], \\
& \sec _{i t}=\beta_{1}+\beta_{2} \text { Lev }_{i t}+\beta_{3} \text { Cap }_{i t}+ \\
& +\beta_{4} \text { Bankspe }_{i t}+\beta_{5} \text { macroec }_{t}+\text { 'Year }_{i}+\varepsilon_{i t} .
\end{aligned}
$$

The study controlled for year effects by introducing year dummies (Year). $\beta$ and $\theta$ are coefficients of the model that capture the effects on the dependent variable, and $\varepsilon_{i t}$ is the error term for bank $i$ in year $t$. Chen, Liu, Opong, and Zhou (2017) and Dionne and Harchaoui (2008) proxied securitization as outstanding securitized assets divided by total assets. Since banks transform portions of their non-saleable loans and backed them by underlying assets of such non-saleable loans, it was deemed appropriate to use total loans as a denominator of securitization ratio $\left(\sec _{i t}\right)$ (Bakoush, Abouarab, and Wolfe, 2019) as shown in Table $1{ }^{1}$

Lev is a non-risk leverage ratio used as an independent risk assessment to act as a back-stop to capital ratio and to limit bank exposure to risk (BCBS, 2017b). Cap it is the Basel IV capital requirement. Starting from Basel III, the formula TCE/RWA should be used as a key capital ratio variable (Yan, Hall, \& Turner, 2012). The RWA takes into account securitization exposures of banks involved in securitization. The composition of RWA in Basel IV introduced a wide range of standardized risk weights for risky and less risky loans within a bank's class assets. Consequently, risk-weights were assigned to individual loan assets from the list of rating bucket provided in Basel IV capital requirements depending on the bank's risk exposure rather than assigning a single risk weight to class asset in Basel II and III, since there may be different risks within the same risk class assets (BCBS, 2016b, 2017; Munoz \& Soler, 2017).

Bank-specific variables $\left(\right.$ Bankspe $\left._{i f}\right)$ include LoanDeposit ratio, a proxy for liquidity ratio. A higher ratio suggests a less liquid bank that may choose securitization to boost its liquidity position (CardoneRiportella, Samaniego-Medina, \& Trujillo-Ponce, 2010). Npatl is a proxy for Credit risk transfer. This study included GDP growth and interest rate proxy (repo rate) to control for the macro-economic environment that may affect the quality of bank assets and consequently may influence the origination of securitization and performance of the securitizing banks (Bakoush, Abouarab, \& Wolfe, 2019; Michalak \& Uhde, 2012). GDP growth is an improved measure of business cycles fluctuation instead of inflation (Bakoush, Abouarab, \& Wolfe, 2019). GDP growth and repo rate may implicitly affect bank asset quality, while the effects of inflation may be subject to banks anticipating inflation or not (Michalak \& Uhde, 2012).

To examine the impact of securitization on performance of commercial banks involved in originating securitization in South Africa, the following model was used in accordance with similar stud-

\begin{tabular}{|c|c|c|c|}
\hline Variable & Definition & Formula & Source \\
\hline sec & Securitization ratio & Outstanding sec asset/Total loans & Bakoush, Abouarab, and Wolfe (2019) \\
\hline$\pi$ & $\mathrm{ROE}$ & NPAT/TE & Gabriel (2016) \\
\hline Lev & Non-risk leverage & Tier1Capital/average-total assets & BCBSa (2017) \\
\hline Cap & Basel IV capital ratios & Tangible common equity/RWA ${ }^{1}$ & BCBSb (2016) \\
\hline Loan ratio & Bankspe & Loan/Deposit & $\begin{array}{c}\text { Cardone-Riportella, Samaniego-Medina, and } \\
\text { Trujillo-Ponce (2010) }\end{array}$ \\
\hline Npatl & Bankspe & Non-performing asset/total loan & $\begin{array}{c}\text { Cardone-Riportella, Samaniego-Medina, and } \\
\text { Trujillo-Ponce (2010) }\end{array}$ \\
\hline Repo rate & macroec & Annual repo-rate & Michalak and Uhde (2012) \\
\hline Gdpgrowth & macroec & Gdp growth rate & Bakoush, Abouarab, and Wolfe (2019) \\
\hline
\end{tabular}
ies (Dionne \& Harchaoui, 2008).

Table 1. Definition of model variables

Note: Expected sign for Lev, Cap, Loan ratio and Npatl is negative.

1 Assumptions made in the calculation of RWA-denominator of the capital ratio: Bank assets used in the calculation of RWA are assumed to be AAA. Commercial loans are assumed to be investment grade. Securitization exposure incorporated into the calculation of RWA uses the SEC-ERBA approach of the revised Basel securitization framework. The numerator of the capital ratio (tce) is held constant. Basel IV requires banks to hold capital for securitization exposures (Chabanel, 2017). 
$\pi=f[$ Lev,Cap, sec,Bankspe, macroec $]$,

$\pi_{i t}=\beta_{1}+\beta_{2}$ Lev $_{i t}+\beta_{3}$ Cap $_{i t}+\beta_{4}$ Bankspe $_{i t}+$

$+\beta_{5} \sec _{i t}+\beta_{6}$ macroec $_{t}+\dot{\theta}$ Year $_{i}+\varepsilon_{i t}$,

where $\pi_{i t}$ is the profitability of the securitizing bank $i$ at time $t$ as measured by return on equity (ROE). Changes in Basel levels require increased capital through the increase in equity. As a result, the study employed ROE as a measure of performance. ROE remains a reflection of profits realized on bank assets for a given capital structure (Gabriel, 2016). For robustness sake, the study also used ROA as an alternative performance measure. Cardone-Riportella, Samaniego-Medina, and Trujillo-Ponce (2010) and Uzun and Webb (2007) explained that large banks securitize due to the inability of smaller banks to finance fixed costs associated with initiating the securitization process, and as a result, bank size is paramount for banks to securitize. This study did not control for size as the selected commercial banks, according to Kasse-Kengne (2017), are the top banks in South Africa and are not significantly different in size. The study employed fixed and random effect models to estimate equations (1) and (2). In addition, the Hausman test and the cross dependency test were used for specification testing.

\section{RESULTS AND DISCUSSION}

The results and interpretations of the estimated models are presented in this section. First, the preliminary descriptive analyses are presented, followed by the fixed effect and random effect results, and specification tests, respectively.

Table 2. Summary statistics of key variables

\subsection{Descriptive statistics}

Table 2 presents the descriptive statistics of key variables. The non-performing assets to total loans ratio (Npatl) showed that 3.8\% of bank loans on average are bad debt. This is an indication of good quality of loans. The loan to deposit ratio shows that on average, South African banks have high loan to deposit ratios, but, on average, they rely on their own deposits to issue loans to their customers. The maximum loan deposit ratio in Table 2 is 165.902, which shows that certain banks in the dataset within the sample period have a loan to deposit ratio above 100. This suggests that such banks may rely on other sources of funding such as securitization to fund loans to customers and to maintain liquidity.

Table 3 shows the frequency of securitization, each originating bank issues per year. It shows that over $75 \%$ of banks issue one securitization, while two banks out of five in the sample issued three securitizations in a given year. This shows that the origination of securitization transactions from commercial banks in South Africa has been low over the years. Saayman and Styger (2003) listed two conditions for securitization growth in South Africa: (1) regulations that favor securitization, and/or (2) the existence of strong demand and supply of securitized assets. These banks were well capitalized above the Basel III minimum capital requirements (Nkopane, 2017). Consequently, there is an opportunity for commercial banks in South Africa to increase origination of securitization for additional liquidity and to generate more loans within the safety of the regulations.

Source: South African Banking Association online database (2019).

\begin{tabular}{|c|c|c|c|c|c|}
\hline Variable & Mean & Std. dev. & Min & Max & Observations \\
\hline $\mathrm{Sec}$ & 1.173 & 1.061 & 0.039 & 5.381 & $N=64$ \\
\hline Lev & 6.384 & 1.641 & 3.083 & 9.419 & $N=52$ \\
\hline Loan_Deposit & 91.849 & 29.194 & 60.413 & 165.902 & $N=80$ \\
\hline Capratio_Basel IV & 11.220 & 6.436 & 2.796 & 33.591 & $N=80$ \\
\hline Capratio_Basel III & 12.739 & 3.655 & 2.901 & 21.057 & $N=75$ \\
\hline Capratio_Basel II & 10.099 & 6.996 & 0.174 & 21.123 & $N=74$ \\
\hline Gdpgrowth & 2.809 & 1.871 & -1.538 & 5.604 & $N=80$ \\
\hline Repo_rate & 7.730 & 2.305 & 5.017 & 12.133 & $N=80$ \\
\hline Npatl & 0.038 & 0.018 & 0.006 & 0.078 & $N=57$ \\
\hline
\end{tabular}


Table 3. Frequency of securitization per bank per year

Source: South African Banking Association online database (2019).

\begin{tabular}{c|c|c|c}
\hline $\begin{array}{c}\text { Number } \\
\text { of securitizations }\end{array}$ & Frequency & Percent & Cum. \\
\hline 1 & 17 & 77.27 & 77.27 \\
\hline 2 & 3 & 13.64 & 90.91 \\
\hline 3 & 2 & 9.09 & 100 \\
\hline Total & 22 & 100 & - \\
\hline
\end{tabular}

\subsection{Interpretation and discussion of results}

The study applied random effects (RE) and fixed effects (FE) models to estimate equations (1) and (2). The Hausman tests selected RE for equation (1) (objective 1) and FE for equation (2) (objective 2). Tables 4 and 5 contain the results of the RE and FE, respectively. Robustness checks were conducted by substituting ROE with ROA to see the effect of changes in Basel capital requirements on the performance of originating banks. However, the results of both measures were similar, so the latter are not reported.

The study examined the effect of capital requirements (under three Basel levels IV, III, II) on the securitization activities of SA banks by estimating Model 1 with the results presented in Table 4 . The results showed that the simulated Basel IV capital ratio has a positive and significant effect on securitization at the $1 \%$ level of significance. Similarly, the Basel III capital ratio also has a positive and significant effect at the 5\% level of significance, while the Basel II capital ratio has no significant effect on securitization. From the result, when South African banks adopted Basel II regulations for the first time, the Basel capital had no significant impact on securitization. As the banks moved from Basel II to Basel III, securitization activities were significantly influenced by capital ratios. Specifically, the change from Basel III to Basel IV may increase securitization in South Africa by $4 \%$, ceteris paribus. The calculated non-risk Basel leverage was significant across the three models at $1 \%$ and $5 \%$ levels of significance, respectively, while macroeconomic variables had no impact on securitization. The Bankspe variables (Loan-deposit and Npal) were found to have a significant negative effect on securitization. The negative effect suggested that liquidity for expansion of loans may not be the main driver of securitization in the South African banks. These findings were contrary to Uzun and Webb (2007) and Dionne and Harchaoui (2008), who found a negative relationship between capital ratios and securitization activities in the US and Canada, respectively. Based on the results of the current study, the implementation of Basel IV can lead to further growth in securitization activities in the South Africa banking sector. The positive coefficient on Capratio_Basel IV suggested that the commercial banks may take on more risk with higher capital requirements.

Table 4. Results of capital requirements and securitization (random effects)

\begin{tabular}{|c|c|c|c|}
\hline \multirow{2}{*}{ Basel level } & IV & III & II \\
\hline & Sec & Sec & Sec \\
\hline \multirow{2}{*}{ Lev } & $-0.337 * * *$ & $-0.289 * *$ & $-0.339 * *$ \\
\hline & $(0.114)$ & $(0.132)$ & $(0.145)$ \\
\hline \multirow{2}{*}{ Loan_Deposit } & $-0.034^{* * *}$ & $-0.021^{*}$ & -0.014 \\
\hline & $(0.011)$ & $(0.012)$ & $(0.012)$ \\
\hline \multirow{2}{*}{ Capratio_Basel IV } & $0.547 * * *$ & - & - \\
\hline & $(0.143)$ & - & - \\
\hline \multirow{2}{*}{ Capratio_Basel III } & - & $0.209 * *$ & - \\
\hline & - & $(0.103)$ & - \\
\hline \multirow{2}{*}{ Capratio_Basel II } & - & - & 0.087 \\
\hline & - & - & $(0.08)$ \\
\hline \multirow{2}{*}{ Gdpgrowth } & -0.381 & -0.151 & -0.041 \\
\hline & $(0.435)$ & $(0.499)$ & $(0.522)$ \\
\hline \multirow{2}{*}{ Repo_rate } & -0.314 & -0.395 & -0.31 \\
\hline & $(0.386)$ & $(0.455)$ & $(0.476)$ \\
\hline \multirow{2}{*}{ Npatl } & $-58.534^{* * *}$ & 12.536 & 9.183 \\
\hline & $(22.047)$ & $(16.739)$ & $(17.521)$ \\
\hline \multirow{2}{*}{ cons } & $4.977^{*}$ & 4.028 & 4.715 \\
\hline & $(2.876)$ & $(3.428)$ & $(3.608)$ \\
\hline $\mathrm{N}$ & 43 & 43 & 43 \\
\hline
\end{tabular}

Note: Standard errors are in parentheses, ${ }^{*} p<0.1$,

$* * p<0.05, * * * p<0.001$.

Results of the effects of securitization on bank performance (Table 5) show that a simulated Basel IV capital ratio and Basel III and II capital ratios have positive and significant effects on $\mathrm{ROE}$ at $10 \%, 1 \%$ and $5 \%$ significance levels, respectively. Loan-deposit ratios have no significant impact on performance of banks that engage in securitization. Similarly, macroeconomic variables had no significant impact on ROE under Basel II and III. Although securitization had a positive effect on the performance of banks under Basel IV, the effect was not significant under any Basel level. 
Table 5. Results of securitization and bank performance (fixed effect)

\begin{tabular}{|c|c|c|c|}
\hline \multirow{2}{*}{ Basel level } & IV & III & II \\
\hline & ROE & ROE & ROE \\
\hline \multirow{2}{*}{ Lev } & 0.852 & $1.314 * *$ & 0.627 \\
\hline & $(0.636)$ & $(0.496)$ & $(0.629)$ \\
\hline \multirow{2}{*}{ Loan_Deposit } & -0.035 & -0.091 & 0.005 \\
\hline & $(0.076)$ & $(0.06)$ & $(0.068)$ \\
\hline \multirow{2}{*}{ Capratio_Basel IV } & $2.536^{*}$ & - & - \\
\hline & (1.369) & - & - \\
\hline \multirow{2}{*}{ Capratio_Basel III } & - & $1.887^{* * *}$ & - \\
\hline & - & $(0.426)$ & - \\
\hline \multirow{2}{*}{ Capratio_Basel II } & - & - & $0.701 * *$ \\
\hline & - & - & $(0.3)$ \\
\hline \multirow{2}{*}{ Gdpgrowth } & 0.362 & 1.039 & 0.738 \\
\hline & $(0.759)$ & $(0.854)$ & $(0.656)$ \\
\hline \multirow{2}{*}{ Repo_rate } & $1.291^{*}$ & 0.287 & 0.572 \\
\hline & $(0.707)$ & $(0.627)$ & (0.419) \\
\hline \multirow{2}{*}{ Npatl } & -206.98 & $-171.083^{*}$ & -131.795 \\
\hline & (128.065) & (91.194) & (111.286) \\
\hline \multirow{2}{*}{$\mathrm{Sec}$} & 0.738 & -0.445 & 0.277 \\
\hline & $(1.068)$ & $(0.883)$ & $(1.053)$ \\
\hline \multirow{2}{*}{ cons } & -7.131 & 5.416 & 4.848 \\
\hline & $(17.219)$ & (8.348) & (13.779) \\
\hline$N$ & 43 & 43 & 43 \\
\hline
\end{tabular}

Note: Standard errors are in parentheses, $* p<0.1,{ }^{* *} p<$ $0.05, * * * p<0.001$.

In essence, one cannot see the effect of securitization on ROE under Basel III and Basel IV, suggesting that securitization activities may not significantly drive bank performance. This finding was consistent with Bannier and Hänsel (2008) and Uzun and Webb (2007), who found that securitization may not have a direct impact on performance of securitizing banks, but it may affect performance through many indirect channels. However, the change in the securitization coefficients, from negative under Basel III to positive under Basel IV, showed the strength of Basel IV to effectively protect banks from securitization exposure as suggested by the new securitization framework.
Overall, the results revealed that tighter capital requirements may increase securitization activities for banks in South Africa under Basel IV. However, the increase in securitization activities under Basel IV may not translate into higher profits for the commercial banks. In other words, the implementation of the Basel IV securitization framework may not have a significant impact on the performance of banks engaged in securitization in South Africa. The implication is that the banks may have to engage in securitization for motives other than having profit as a primary motive.

\subsection{Specification tests}

The study conducted Pesaran and Frees tests for fixed and random effects models to measure the $H_{0}$ of no cross dependence against the $H_{1}$ of cross dependence among the variables. For equation (1), results in Table $4, H_{0}$ of no cross dependence was rejected. However, Frees cross dependency test showed that the calculated test is less than critical values, which indicated failure to reject the $H_{0}$ of no cross dependence. Since the Pesaran test had a cross dependency with high correlation of 0.46 (FE) and 0.56 (RE), which conflicted with Frees test, the random effect is an efficient and consistent estimator as confirmed by the Hausman test for equation (1). For the results of equation (2) in Table 5, the Pesaran test rejected the $H_{0}$ of no cross dependency $(p<5 \%)$. However, the presence of cross dependency was weak, given average absolute correlation of 0.37 (FE) and 0.34 (RE). A further test using Frees showed that there was no cross dependency under FE and this was confirmed by the Hausman test. As a result, the FE model was considered to be a consistent and efficient estimator for equation (2).

\section{CONCLUSION}

The study analyzed the potential impact of the proposed Basel IV capital requirements on securitization and performance of commercial banks involved in securitization in South Africa, using historical financial data. The study firstly concluded that more stringent Basel IV capital requirements will have a positive and significant impact on securitization activities of banks in South Africa. One can expect a negative impact on control for risk, but the positive result suggests that higher Basel capital requirements will increase securitization activities and may simultaneously increase bank risk-taking. Secondly, securitization had no impact on the performance of securitizing banks. This could have been 
caused by the high cost of originating securitization, such as payment of interest to investors, issuance costs, rating agency, legal costs, and other related floatation costs, which may not increase profits of originating banks. Securitization may enhance the performance of banks through indirect channels, according to certain literature. In conclusion, higher capital requirements of Basel IV are expected to lead to a significant increase in securitization activities, but the performance of securitizing banks may improve in the long term.

According to the Basel Committee, the aim of the new securitization framework is to re-establish securitization activities within an adequately capitalized regulatory environment. A clearer and simple securitization approach for banks introduced by the revised 2016 securitization framework can be a motivation for more banks to securitize provided they are ready to comply with more stringent capital requirements and transparent disclosures in the securitization process. Reducing dependence on credit rating agencies introduced by the revised securitization framework of 2016 may reduce the cost of originating securitization, which can lead to an increase in the performance of banks that engage in securitization. Observation of non-banking sector data from Bloomberg Online Database (2019) shows that there is a growing successful origination and execution of securitization transactions in the South African securitization market, indicating that there are investors available to buy securitized assets. As a result, it will be beneficial for South African banks to implement Basel IV capital requirements and the revised securitization framework of 2016 to further ensure that the banks are adequately protected from securitization exposures while increasing securitization activities. This study contributed to the literature by investigating the probable effect of the proposed Basel IV on the securitization and performance of the South African Banking sector. The study recommended the adoption of the new Basel regulation by the South African commercial banks, as it is expected to stimulate liquidity and mitigate credit risk through increased securitization activities. Subsequently, this study found no evidence to support the effect of Basel IV implementation on the performance of securitizing banks, but a more detailed long-run analysis may provide different results. Consequently, future studies can employ more advanced forward-looking models to examine whether Basel IV can improve bank performance in the long run, as suggested in the literature.

\section{ACKNOWLEDGMENT}

The authors appreciate the feedback received at the 2019 Economic Society of South Africa Conference for improving this manuscript.

\section{AUTHOR CONTRIBUTIONS}

Conceptualization: Damilola Oyetade, Paul-Francois Muzindutsi.

Data curation: Damilola Oyetade.

Formal analysis: Damilola Oyetade, Adefemi A. Obalade, Paul-Francois Muzindutsi.

Investigation: Damilola Oyetade.

Methodology: Damilola Oyetade, Adefemi A. Obalade, Paul-Francois Muzindutsi.

Project administration: Damilola Oyetade.

Resources: Damilola Oyetade, Paul-Francois Muzindutsi.

Software: Damilola Oyetade, Paul-Francois Muzindutsi.

Supervision: Adefemi A. Obalade, Paul-Francois Muzindutsi.

Validation: Adefemi A. Obalade, Paul-Francois Muzindutsi.

Writing - original draft: Damilola Oyetade, Paul-Francois Muzindutsi.

Writing - reviewing \& editing: Damilola Oyetade, Adefemi A. Obalade, Paul-Francois Muzindutsi. 


\section{REFERENCES}

1. Bakoush, M., Abouarab, R., \& Wolfe, S. (2019). Disentangling the impact of securitization on bank profitability. Journal of Research in International Business Finance, 47, 519-537. https://doi.org/10.1016/j. ribaf.2018.09.013

2. Balin, B. J. (2008). Basel I, Basel II, and emerging markets: A Nontechnical Analysis. SSRN. Retrieved from https://ssrn.com/ abstract $=1477712$

3. Bannier, C. E., \& Hänsel, D. N. (2008). Determinants of European Banks' Engagement in Loan Securitization (Discussion Paper No. 10/2008). Deutsche Bundesbank. Retrieved from https://www.bundesbank. de/resource/blob/704276/ d7a4b54529f5bc57bf07df0aa74689d0/mL/2008-06-02-dkp10-data.pdf

4. BCBS. (2009). Strengthening the resilience of the banking sector. Bank for International Settlements. Retrieved from https://www.bis. org/publ/bcbs164.pdf

5. BCBS. (2016a). Revisions to the securitization framework. Amended to include the alternative capital treatment for "simple, transparent and comparable" securitizations. Bank for International Settlements. Retrieved from https://www.bis. org/bcbs/publ/d374.pdf

6. BCBS. (2016b). Standardised Measurement Approach for operational risk. Bank for International Settlements. Retrieved from https://www.bis. org/bcbs/publ/d355.pdf

7. BCBS. (2017a). Basel III: Finalising post-crisis reforms. Bank for International Settlements. Retrieved from https://www.bis. org/bcbs/publ/d424.pdf

8. BCBS. (2017b). Finalising Basel III in brief. Bank for International Settlements. Retrieved from https://www.bis.org/bcbs/publ/ d424_inbrief.pdf

9. Beck, T., Jones, E., \& Knaack, P. (2019). Basel III in Developing Countries - A difficult relationship. International Banker. Retrieved from https://internationalbanker.com/banking/ basel-iii-in-developing-countriesa-difficult-relationship/

10. Bloomberg Online Database. (2019). Bloomberg Professional Services. Retrieved from https:// www.bloomberg.com/professional/

11. Carbó-Valverde, S., MarquésIbáñez, D., \& Fernandez, F. R. (2011). Securitization, Bank Lending and Credit Quality: The Case of Spain (ECB Working Paper, No. 1329). European Central Bank (ECB), Frankfurt am Main, Germany. Retrieved from https:// www.ecb.europa.eu/pub/pdf/scpwps/ecbwp1329.pdf

12. Cardone-Riportella, C., Samaniego-Medina, R., \& TrujilloPonce, A. (2010). What drives bank securitisation? The Spanish experience. Journal of Banking \& Finance, 34(11), 2639-2651. https://doi.org/10.1016/j.jbankfin.2010.05.003

13. Castellani, D. (2018). Mortgagebacked Securitization and SME Lending During the Financial and Economic Crisis: Evidence from the Italian Cooperative Banking System. Economic Notes, 47(1), 187-222. https://doi.org/10.1111/ ecno.12096

14. Casu, B., Clare, A., Sarkisyan, A., \& Thomas, S. (2013). Securitization and Bank Performance. Journal of Money, Credit and Banking, 45(8), 16171658. https://doi.org/10.1111/ jmcb.12064

15. Chabanel, P. (2017). Capital calculations under the revised securitization framework. Moody Analytics. Retrieved from https:// www.moodysanalytics.com/-/ media/whitepaper/2017/capitalcalculations-under-the-revisedsecuritasation-framework.pdf

16. Chen, Z., Liu, F. H., Opong, K., \& Zhou, M. (2017). Short-term safety or long-term failure? Empirical evidence of the impact of securitization on bank risk. Journal of International Money and Finance, 72, 48-74. https://doi.org/10.1016/j.jimonfin.2016.12.003

17. Dionne, G., \& Harchaoui, T. M. (2008). Banks' capital, securitization and credit risk: An empirical evidence for Canada. Journal of Insurance and Risk Management, 75(4), 459-485. Retrieved from http://www. revueassurances.ca/wp-content/ uploads/2016/02/2008_75_no4_ Dionne1.pdf

18. Gabriel, G. (2016). The impact of the basel 3 capital requirements on the performance of european banks (Master's Thesis). Retrieved from https://matheo.uliege.be/ bitstream/2268.2/1837/4/The $\% 20$ impact $\% 20$ of\%20Basel $\% 20 I I I \% 20$ capital\%20requirements $\% 20$ on $\% 20$ the $\% 20$ performance $\% 20$ of\%20European\%20banks.pdf.

19. Ghosh, A. (2018). Implications of securitisation on bank performance: evidence from US commercial banks. International Journal of Financial Innovation in Banking, 2(1), 1-28. Retrieved from https://www.inderscience. com/offer.php?id=92417

20. Giordana, G. A., \& Schumacher, I. (2017). An Empirical Study on the Impact of Basel III Standards on Banks' Default Risk: The Case of Luxembourg. Journal of Risk and Financial Management, 10(2), 8. https://doi.org/10.3390/ jrfm10020008

21. Goddard, J., Liu, H., Molyneux, P., \& Wilson, J. O. (2013). Do bank profits converge? European Financial Management, 19(2), 345-365. https://doi.org/10.1111/ j.1468-036X.2010.00578.x

22. Greenbaum, S. I., \& Thakor, A. V. (1987). Bank funding modes: Securitization versus deposits. Journal of Banking and Finance, 11(3), 379-401. https://doi. org/10.1016/0378-4266(87)900409

23. Haubrich, J. G., \& Wachtel, P. (1993). Capital requirements and shifts in commercial bank 
portfolios. Federal Reserve Bank of Cleveland, Economic Review, 29(3), 02-15. Retrieved from http://citeseerx.ist.psu.edu/viewdoc/downlo ad?doi $=10.1 \cdot 1.361 .8976 \&$ rep $=$ rep 1 \&type $=$ pdf

24. Jablecki, J. (2009). The impact of Basel I capital requirements on bank behavior and the efficacy of monetary policy. International Journal of Economic Sciences and Applied Research, 2(1), 16-35. Retrieved from http://ijbesar. teiemt.gr/docs/volume2_issue1/ impact_basel.pdf

25. Jiangli, W., \& Pritsker, M. (2008). The impacts of securitization on US bank holding companies (Working Paper). Federal Reserve Bank Chicago, Chicago. Retrieved from https://papers.ssrn.com/sol3/papers.cfm?abstract_id=1102284

26. Kargi, H. S. (2011). Credit risk and the performance of Nigerian banks. Ahmadu Bello University, Zaria. Retrieved from https:// www.academia.edu/8637351/ CREDIT_RISK_AND_THE_PERFORMANCE_OF_NIGERIAN_ BANKS_BY

27. Kasse-Kengne, S. (2017). Securitisation of mortgage loans, regulatory capital arbitrage and bank stability in South Africa: Econometric and theoretic analyses (Ph.D. Thesis). University of Cape Town. Retrieved from https:// open.uct.ac.za/bitstream/handle/11427/28418/Kasse_Kengne_ Securitisation_mortgage_2018_1. pdf? sequence $=1$ \&isAllowed $=y$

28. Keys, B. J., Mukherjee, T., Seru, A., \& Vig, V. (2010). Did securitization lead to lax screening? Evidence from subprime loans. The Quarterly Journal of Economics, 125(1), 307-362. https://doi.org/10.1162/ qjec.2010.125.1.307

29. Krainer, J., \& Laderman, E. (2014). Mortgage loan securitization and relative loan performance. Journal of Financial Services Research, 45(1), 39-66. https://doi. org/10.1007/s10693-013-0161-7

30. Michalak, T. C., \& Uhde, A. (2012). Credit risk securitization and bank soundness in Europe. The Quarterly Review of
Economics and Finance, 52(3), 272-285. https://doi.org/10.1016/j. qref.2012.04.008

31. Mohan, T. P., \& George, R. G. (2013). Basel 2.5 and Basel III: The Impact of the New Capital (and Liquidity) Rules on Securitization. Journal of Structured Finance, 18(4), 77-100. https://doi. org/10.3905/jsf.2013.18.4.077

32. Moyo, Z., \& Firer, C. (2008). Securitisation in South Africa: 2000-2007. South African Journal of Business Management, 39(1), 27-34. https://doi.org/10.4102/ sajbm.v39i1.553

33. Munoz, S., \& Soler, P. (2017). Basel III End Game. Regulations and Public Policies, 1-8. Retrieved from https://www.bbvaresearch.com/ wp-content/uploads/2017/12/ Watch-Basel-IV.pdf

34. Nkopane, T. (2017). The relevance of the Basel III Accord within the South African banking system (Master's Thesis). University of the Witwatersrand. Retrieved from http://wiredspace.wits.ac.za/ handle/10539/23804

35. Ombaka, C., \& Jagongo, A. (2018). Mergers and acquisitions on financial performance among selected commercial banks, Kenya. International Academic Journal of Economics and Finance, 3(1), 1-23. Retrieved from https://www. iajournals.org/articles/iajef_v3_ i1_1_23.pdf

36. Pavel, C. A., \& Phillis, D. (1987). Why commercial banks sell loans: An empirical analysis. Economic Perspectives, 11(3), 1-14. Retrieved from https://econpapers.repec.org/article/fipfedhep/ y_3a1987_3ai_3amay_3ap_3a314_3an_3av.11no.3.htm

37. Prinsloo, H. (2009). Real Estate Securitisation: Viable Method of Finance in South Africa? In 16th Annual European Real Estate Society Conference. ERES: Conference. Stockholm, Sweden, 2009. Retrieved from https://econpapers.repec.org/paper/arzwpaper/eres2009_5f337.htm

38. Robinson, R. I. (1941). The Capital-Deposit Ratio in Banking Supervision. Journal of Political
Economy, 49(1), 41-57. https://doi. org/10.1086/255666

39. Saayman, A., \& Styger, P. (2003). Securitisation in South Africa: historic deficiencies and future outlook. South African Journal of Economic and Management Sciences, 6(4), 744-764. https://doi. org/10.4102/sajems.v6i4.1515

40. Sadien, E. (2017). The impact of the change from Basel II to Basel III on the profitability of the South African Banking Sector (Master's Thesis). University of Capetown. Retrieved from https://open.uct.ac.za/bitstream/ handle/11427/27387/thesis_com_2017_sadien_ebrahim. pdf? sequence $=1$

41. Sarkisyan, A. (2011). Three essays on securitisation (Doctoral Thesis). City University London. Retrieved from https://openaccess.city.ac.uk/ $\mathrm{id} /$ eprint/1171/

42. The Banking Association South Africa. (2019). Traditional Securitisation transactions by the South African Banks. Retrieved from http://securitisation. banking.org.za/by_asset_class. php?year $=2019 \&$ Submit $=$ Go

43. Uzun, H., \& Webb, E. (2007). Securitization and risk: empirical evidence on US banks. The Journal of Risk Finance, 8(1), 11-23. https://doi. org/10.1108/15265940710721046

44. Walter, J. R. (2019). US Bank Capital Regulation: History and Changes Since the Financial Crisis. Economic Quarterly, 105(1), 1-40. https://doi.org/10.21144/ eq1050101

45. White, J. P. L. (2011). The role of securitisation and credit default swaps in the credit crisis: a South African perspective. North-West University. Retrieved from http:// hdl.handle.net/10394/7581

46. Yan, M., Hall, M. J. B., \& Turner, P. (2012). A cost-benefit analysis of Basel III: Some evidence from the UK. International Review of Financial Analysis, 25, 7382. https://doi.org/10.1016/j. irfa.2012.06.009 